\title{
INNOVATIVE APPROACHES TO ESTIMATION OF LOGISTIC POTENTIAL AND THE PURPOSE OF LOGISTIC REGIONAL OUTSOURCING DEVELOPMENT
}

\author{
Inna Irtysheva ${ }^{1}$ \\ Admiral Makarov National University of Shipbuilding, Ukraine
}

Marianna Stehnei ${ }^{2}$

Mukachevo State University, Ukraine

Kostjantyn Zavhorodnij ${ }^{3}$

State Enterprise "Production Association Southern Machine-Building Plant named after A.M. Makarov", Ukraine

\begin{abstract}
The aim of the article is to summarize scientific approaches to the definition of the category "logistics potential", the justification of the methodology for assessing the favourability for the development of logistics outsourcing of regions of Ukraine. Methodology. We suggest investigating the level of favourability for the development of the logistics-outsourcing system of the region through an integrated assessment of its following components: infrastructure and logistics, socio-economic, transport, geographic. The calculation of the integral indicator for assessing the level of favourability for the development of the logistics-outsourcing system of regions of the country is carried out on the basis of summing the rank values of each of the abovementioned list of the synthetic component. $l=\sum l_{i}+\sum l_{j}+\sum e_{k}+\sum t_{m}+\sum g_{n}(i=1, \ldots 7 ; j=1, \ldots 5 ; k=1, \ldots 6 ; n=1, \ldots 4)$. Separate components play an equal role in assessing the favourability for the development of the logistics-outsourcing system in the region. According to the final integral indicator, the place (rating) of each region is determined from the point of view of the potential of the logistics-outsourcing system of the region in the general composition of regions of the country. The suggested methodology for assessing the regions according to the level of favourability for the development of the logistics-outsourcing system provides an opportunity to compare the regions, identify the weak spots in the development of logistics services of regions in terms of components (infrastructure-logistic, socio-economic, transport, geographic), and find ways to improve regional logistics infrastructure and logistics outsourcing. Results of the analysis showed that under other equivalent conditions, the variation of the gross regional product by $65.73 \%$ depends on the variation of capital investment in transport, warehousing, postal and courier activities, and this dependence is logarithmic. Value/originality. A methodology for evaluating the favourability for the development of logistics outsourcing of the regions is proposed, the use of which enables to determine perspective directions of development of regional logistics infrastructure.
\end{abstract}

Key words: logistics potential, logistics outsourcing, logistics infrastructure, regional development.

JEL Classification: C13, L90, O18, R49

\section{Introduction}

At the modern stage of development of transformation processes in the economy of Ukraine, a considerable attention should be drawn to the process of formation of regional logistics-outsourcing systems, which purpose of functioning is to form an effective complex of logistics services and optimize logistics regional infrastructure based on the use of specialized (external) sources of logistics services. All this will allow optimizing structural proportions of production of a regional product and systematizing information, financial, and commodity flows of the region.

Importance of study and substantiation of development of logistics outsourcing at the level of

\footnotetext{
Corresponding author:

${ }^{1}$ Department Management, Admiral Makarov National University of Shipbuilding.

E-mail: innauamd@gmail.com

${ }^{2}$ Department of Finance, Mukachevo State University.

E-mail: stegneym@gmail.com

${ }^{3}$ State Enterprise "Production Association Southern Machine-Building Plant named after A.M. Makarov".

E-mail: info@yuzmashair.com.ua
} 
the state, region, and enterprises is confirmed both by the theory and practice. So, according to data from the European Business Association, the bulk of the total cost of time of the process of turnover is the cost of warehousing, delivery, and other logistics operations.

Theoretical substantiations of logistics potential are reflected in the works of the following domestic and foreign scholars: Syzdykbaieva B., Raimbekov Zh., Zhumataieva B., Freidman O. A., Oklander M. A. Issues of development of logistics outsourcing are outlined in the works of Moroz O. D., Semenenko A. I. However, these papers most often consider the concept of logistics from the viewpoint of enterprises or at the state level, more rarely - at the regional level.

The necessity and appropriateness of further inquiries of the declared subjects is determined by the lack of methodology for assessing the regions of Ukraine in terms of favourability to the development of logistics and logistics outsourcing, which would be based on statistical data of bodies of State Statistics Service and substantiate (prove or refute) expert estimations of the level of regional development of logistics, which are most often based on experience and intuition.

The purpose of the article is to summarize scientific approaches to the definition of the category "logistics potential", substantiate the methodology for assessing the favourability for the development of logistics outsourcing of regions of Ukraine.

\section{Theoretical approaches to the determination of logistics potential of the region}

The rationality of formation of regional logisticsoutsourcing systems is confirmed by the fact that they will promote an increase in the level of investment attractiveness of the region and innovative development of business processes. And, as a consequence, the level of the population well-being in the region will improve.

Analysis of works of scholars testifies that most of the attention is paid to the assessment of regional transport potential (Moroz, 2010; Syzdykbaeva \& Raymbekov, 2013), and what about the assessment of logistics potential, corresponding assessments are mostly based on expert estimations (Freydman, 2013; Rakhmanhulov \& Kopylova, 2014), which cannot always be confirmed by statistical data. Moreover, in our view, it is not enough to talk about logistics potential of the region, but appropriate to consider the regional logistics-outsourcing system. Therefore, the lack of a single approach to the evaluation of the logisticsoutsourcing development of the region proves the necessity to conduct further inquiries in this direction.

Thus, in order to ensure development and socioeconomic growth of the region, it is necessary to investigate the essence of the concept of logistics potential. When interpreting the concept of logistics potential of the region, Moroz O. D. (Moroz, 2010) affirms that "it is possibilities of the region, which are related to ensuring the efficient movement of economic flows of the region," and a group of scholars Syzdykbaieva B., Raimbekov Zh., Zhumataieva B. (Syzdykbaeva \& Raymbekov, 2013) define this category "an aggregate of indicators or factors that characterize strength, sources, capabilities, means, and other reserves that can be used in economic activity." Freidman O. A. (Freydman, 2013) defines logistics potential as "an ability of a logistics regional system to ensure timely movement of material resources through the use of transport, warehouse, personnel, and climatogeographic resources of the region."

In the given definitions of the logistic potential of the region, some scientists define it through the possibilities of the region, and others through a set of indicators. In our view, the potential is capabilities, and economic assessment of potential is carried out by using a set of indicators. We are leaning towards a universal logistics concept based on the provisions (Oklander, 2008):

"- allocation of material flow as a holistic object of management;

- construction of a logistics system - organizational and management mechanism of coordination that allows achieving effect due to a clear coherence in the actions of specialists of various services participating in the material management;

- taking into account integral rather than local costs, accompanying material flow, and losses caused by inappropriate use of flow resources".

\section{Evaluation of favourability for the development of logistics outsourcing of the region}

Considering the understanding of different scientists of the concept of the logistic potential of the region, we propose to investigate the level of favourability for the development of a logistics-outsourcing system of the region through the integrated assessment of its following components:

- infrastructural-logistics;

- socio-economic;

- transport,;

- geographic.

Characteristics of the components of the methodology for assessing the favourability for the development of a logistics-outsourcing system of the region are presented in Table 1. Infrastructural-logistics component covers 7 characteristics, socio-economic component 5 characteristics, transport -6 , geographic component covers 4 characteristics.

The calculation of the integral indicator for assessing the level of favourability for the development of the logistics-outsourcing system of the country's regions is carried out on the basis of summing the rank values of each of the above list of the synthetic component. 
Table 1

Characteristics of the components of the methodology for assessing the favourability for the development of the regional logistics-outsourcing system (the authors' own development)

\begin{tabular}{|c|c|}
\hline $\begin{array}{c}\text { Components of } \\
\text { assessment }\end{array}$ & Components of synthetic evaluation indicators \\
\hline $\begin{array}{l}\text { Infrastructural- } \\
\text { logistics }\end{array}$ & $\begin{array}{l}\text { - Number of logistics companies with outsourcing services }\left(l_{1}\right) \\
\text { - Number of subjects of EDRPOU }\left(l_{2}\right) \\
\text { - Number of legal entities }\left(l_{3}\right) \\
\text { - Filling stations by regions }\left(l_{4}\right) \\
\text { - The density of railways of general use by regions, km per } 1 \text { ths.sq.km of territory }\left(l_{5}\right) \\
\text { - Length of public highways by regions, ths.km }\left(l_{6}\right) \\
\text { - The share of surfaced roads in total length by regions }\left(l_{7}\right)\end{array}$ \\
\hline socio-economic & $\begin{array}{l}\text { - An average number of employees of enterprises of the type of economic activity "Transport, Warehousing, Postal and } \\
\text { Courier Activities" by regions, ths. people }\left(e_{1}\right) \\
\text { - The average number of full-time employees of enterprises of types of economic activity "Ground and Pipeline } \\
\text { Transport", "Water Transport" and "Aviation Transport" by regions, thousand }\left(e_{2}\right) \\
\text { - An average number of employees of enterprises of the type of economic activity "Post and Courier Activities" by } \\
\text { regions, ths. people }\left(e_{3}\right) \\
\text { - Profitability of all activity of enterprises by type of economic activity “Transport, Warehousing, Postal and Courier } \\
\text { Activities" by regions }\left(e_{4}\right) \\
\text { - Profitability of all activity of enterprises by type of economic activity “Telecommunications (Electric } \\
\text { Communication)" by regions }\left(e_{5}\right)\end{array}$ \\
\hline transport & $\begin{array}{l}\text { - Cargo turnover of motor transport enterprises by regions, million tkm }\left(t_{1}\right) \\
\text { - Cargo turnover of maritime transport by regions, million tkm }\left(t_{2}\right) \\
\text { - Cargo turnover of river transport by regions, million tkm }\left(t_{3}\right) \\
\text { - The average distance of transportation of one ton of goods by motor transport enterprises by regions, } \mathrm{km}\left(t_{4}\right) \\
\text { - The average distance of transportation of one ton of goods by maritime transport by regions, } \mathrm{km}\left(t_{5}\right) \\
\text { - The average distance of transportation of one ton of goods by river transport by regions, } \mathrm{km}\left(t_{6}\right)\end{array}$ \\
\hline geographic & $\begin{array}{l}\text { - Area of the region, ths. ha }\left(g_{1}\right) \\
\text { - Proximity to the capital, } \mathrm{km}\left(g_{2}\right) \\
\text { - Common border with other states (number of neighbours), }\left(g_{3}\right) \\
\text { - Access to the sea, }\left(g_{4}\right)\end{array}$ \\
\hline
\end{tabular}

$$
\begin{aligned}
& I=\sum l_{i}+\sum l_{j}+\sum e_{k}+\sum t_{m}+\sum g_{n}, \\
& i=1, \ldots 7 ; j=1, \ldots 5 ; k=1, \ldots 6 ; n=1, \ldots 4 .
\end{aligned}
$$

Separate components play an equal role in assessing the favourability for the development of the logisticsoutsourcing system in the region. According to the final integral indicator, the place (rating) of each region is determined from the point of view of the assessment of the potential or favourability for the development of the logistics-outsourcing system of the region in the overall composition of regions of the country.

In order to evaluate the level of favourability for the development of a logistics-outsourcing system of regions of Ukraine, let us use the consolidated data for 2016 from the statistical collection "Regions of Ukraine, 2016" and the statistical collection "Transport and Communications of Ukraine - 2016”.

The first component of the methodology for assessing the favourability of development of a logisticsoutsourcing system of the region is called infrastructurallogistics and covers seven statistical indicators:

- Number of logistics companies with outsourcing services $\left(l_{1}\right)$;

- Number of subjects of EDRPOU $\left(l_{2}\right)$;

- Number of legal entities $\left(l_{3}\right)$;

- Filling stations by regions $\left(l_{4}\right)$;
- The density of railways of general use by regions, $\mathrm{km}$ per 1 ths.sq.km of territory $\left(l_{5}\right)$;

- Length of public highways by regions, ths.km $\left(l_{6}\right)$;

- The share of surfaced roads in total length by regions $\left(l_{7}\right)$.

The numerical values of indicators of the infrastructural-logistic component are given in Table 2.

The ranking of all indicators of the infrastructurallogistics component is carried out in ascending order. The smallest value will correspond to rank 1 , and the largest one will correspond to 24 , the ranking results are given in Table 3.

Thus, by the level of development of infrastructurallogistics component according to the methodology for assessing the logistics-outsourcing system of the region, first three positions of the ranking belong to Dnipropetrovsk, Kharkiv, and Donetsk regions. The last place by the level of the infrastructural-logistics component is occupied by Volyn region.

In the same way, we conducted the assessment of the regional logistics-outsourcing system by other components: socio-economic, transport, geographic.

The calculation of the integral indicator for assessing the level of development of the logistics-outsourcing system of the country's regions is carried out on the basis of summing the rank values of each of the above list of 
Vol. 4, No. 2, 2018

Table 2

Indicators of the infrastructural-logistic component of the methodology for assessing the favourability for the development of a logistics-outsourcing system of the region (compiled by the authors according to data of the statistical collection "Regions of Ukraine, 2016" and the statistical collection "Transport and Communications of Ukraine - 2016")

\begin{tabular}{|l|c|c|c|c|c|c|c|}
\hline Regions of Ukraine & $\left(l_{1}\right)$ & $\left(l_{2}\right)$ & $\left(l_{3}\right)$ & $\left(l_{4}\right)$ & $\left(l_{5}\right)$ & $\left(l_{6}\right)$ & $\left(l_{7}\right)$ \\
\hline Vinnytsia & 431 & 28706 & 27349 & 299 & 41 & 9,0 & 94,3 \\
\hline Volyn & 51 & 19436 & 18673 & 169 & 30 & 5,8 & 93,6 \\
\hline Dnipropetrovsk & 622 & 95071 & 92438 & 459 & 49 & 9,2 & 99,9 \\
\hline Donetsk & 376 & 86568 & 84073 & 250 & 59 & 8,0 & 99,2 \\
\hline Zhytomyr & 135 & 28286 & 27160 & 215 & 34 & 8,3 & 97,5 \\
\hline Zakarpattia & 61 & 20856 & 19987 & 255 & 47 & 3,3 & 99,7 \\
\hline Zaporizhzhia & 385 & 44733 & 43274 & 307 & 36 & 6,8 & 97,6 \\
\hline Ivano-Frankivsk & 48 & 25563 & 24326 & 185 & 36 & 4,1 & 100,0 \\
\hline Kyiv & 1949 & 57136 & 55351 & 511 & 28 & 8,6 & 99,8 \\
\hline Kirovohrad & 71 & 21621 & 20714 & 217 & 36 & 6,2 & 98,5 \\
\hline Luhansk & 234 & 41373 & 39850 & 97 & 41 & 5,8 & 99,2 \\
\hline Lviv & 261 & 60137 & 57750 & 383 & 58 & 8,2 & 97,9 \\
\hline Mykolaiv & 160 & 42152 & 41047 & 238 & 29 & 4,8 & 99,7 \\
\hline Odesa & 633 & 70369 & 68103 & 410 & 31 & 8,1 & 97,3 \\
\hline Poltava & 264 & 31482 & 30147 & 273 & 30 & 8,9 & 99,99 \\
\hline Rivne & 90 & 20262 & 19446 & 177 & 29 & 5,1 & 98,6 \\
\hline Sumy & 100 & 21984 & 21074 & 147 & 30 & 6,7 & 93,1 \\
\hline Ternopil & 44 & 20032 & 19271 & 185 & 41 & 5,0 & 99,5 \\
\hline Kharkiv & 828 & 69054 & 67297 & 553 & 48 & 9,4 & 97,5 \\
\hline Kherson & 96 & 25639 & 24726 & 222 & 16 & 5,0 & 99,3 \\
\hline Khmelnytskyi & 44 & 27981 & 26908 & 233 & 36 & 7,1 & 99,3 \\
\hline Cherkasy & 140 & 25911 & 24739 & 247 & 28 & 5,9 & 97,2 \\
\hline Chernivtsi & 45 & 15371 & 14709 & 179 & 51 & 2,9 & 99,8 \\
\hline Chernihiv & 36 & 20742 & 19786 & 169 & 27 & 7,2 & 93,7 \\
\hline
\end{tabular}

Table 3

Evaluation of rank values of indicators of an infrastructural-logistics component of the methodology for assessing the favourability for the development of a logistics-outsourcing system of the region

\begin{tabular}{|l|c|c|c|c|c|c|c|c|c|}
\hline Regions of Ukraine & $\mathrm{R}\left(l_{1}\right)$ & $\mathrm{R}\left(l_{2}\right)$ & $\mathrm{R}\left(l_{3}\right)$ & $\mathrm{R}\left(l_{4}\right)$ & $\mathrm{R}\left(l_{5}\right)$ & $\mathrm{R}\left(l_{6}\right)$ & $\mathrm{R}\left(l_{7}\right)$ & $\mathrm{R}(l)$ & Region's ranking $(l)$ \\
\hline Vinnytsia & 20 & 14 & 14 & 18 & 16 & 22 & 4 & 108 & 8 \\
\hline Volyn & 6 & 2 & 2 & 3 & 7 & 8 & 2 & 30 & 24 \\
\hline Dnipropetrovsk & 21 & 24 & 24 & 22 & 21 & 23 & 22 & 157 & 1 \\
\hline Donetsk & 18 & 23 & 23 & 15 & 24 & 16 & 13 & 132 & 3 \\
\hline Zhytomyr & 12 & 13 & 13 & 9 & 11 & 19 & 7 & 84 & 12 \\
\hline Zakarpattia & 7 & 6 & 6 & 16 & 19 & 2 & 18 & 74 & 14 \\
\hline Zaporizhzhia & 19 & 18 & 18 & 19 & 12 & 13 & 9 & 108 & 8 \\
\hline Ivano-Frankivsk & 5 & 9 & 9 & 7 & 12 & 3 & 24 & 69 & 15 \\
\hline Kyiv & 24 & 19 & 19 & 23 & 3 & 20 & 20 & 128 & 4 \\
\hline Kirovohrad & 8 & 7 & 7 & 10 & 12 & 11 & 11 & 66 & 17 \\
\hline Luhansk & 15 & 16 & 16 & 1 & 16 & 8 & 13 & 85 & 11 \\
\hline Lviv & 16 & 20 & 20 & 20 & 23 & 18 & 10 & 127 & 5 \\
\hline Mykolaiv & 14 & 17 & 17 & 13 & 5 & 4 & 18 & 88 & 10 \\
\hline Odesa & 22 & 22 & 22 & 21 & 10 & 17 & 6 & 120 & 6 \\
\hline Poltava & 17 & 15 & 15 & 17 & 7 & 21 & 23 & 115 & 7 \\
\hline Rivne & 9 & 4 & 4 & 5 & 5 & 7 & 12 & 46 & 22 \\
\hline Sumy & 11 & 8 & 8 & 2 & 7 & 12 & 1 & 49 & 21 \\
\hline Ternopil & 2 & 3 & 3 & 7 & 16 & 5 & 17 & 53 & 20 \\
\hline Kharkiv & 23 & 21 & 21 & 24 & 20 & 24 & 7 & 140 & 2 \\
\hline Kherson & 10 & 10 & 10 & 11 & 1 & 5 & 15 & 62 & 18 \\
\hline Khmelnytskyi & 2 & 12 & 12 & 12 & 12 & 14 & 15 & 79 & 13 \\
\hline Cherkasy & 13 & 11 & 11 & 14 & 3 & 10 & 5 & 67 & 16 \\
\hline Chernivtsi & 4 & 1 & 1 & 6 & 22 & 1 & 20 & 55 & 19 \\
\hline Chernihiv & 1 & 5 & 5 & 3 & 2 & 15 & 3 & 34 & 23 \\
\hline
\end{tabular}


the synthetic component. Regions' ranking according to the level of development of the logistics-outsourcing system is determined based on ranging (in descending order) of the integral indicator (see Table 4).

Thus, by the level of favourability for the development of the logistics-outsourcing system, Dnipropetrovsk region is in the first place. The second place is occupied by Kharkiv, and the third place - Lviv region. On the last place of the tanking of favourability for the development of the logistics-outsourcing system is Chernivtsi region.

According to materials of the Development Strategy of Dnipropetrovsk region: "Dnipropetrovsk region one of the most economically developed regions of Ukraine. However, the current structure of its economy is not a guarantee for the accelerated development of Dnipropetrovsk region for the next period and a guarantee of stable improvement of the quality of life of inhabitants of the region for the medium term".

Despite the fact that the density of all the roads of the regional significance of the Dnipropetrovsk region is lower than the average in Ukraine, the railway infrastructure of the region is better than road transport. It is these special characteristics of the region and a significant number of industrial enterprises that provide additional grounds for considering Dnipropetrovsk region today the most favourable region of Ukraine for the development of a logistics and outsourcing system.
The proposed methodology for assessing the regions by the level of favourability for the development of the logistics-outsourcing system allows comparing regions, revealing weaknesses of the sphere of development of logistics services of regions in the view of components (infrastructural-logistics, socio-economic, transport, geographic), and finding ways to improve regional logistics infrastructure and logistics outsourcing.

\section{Gross regional product and transport investments}

In the framework of the study, it was interesting to analyse the dependence of the gross regional product on the size of investment resources in transport, warehousing, postal and courier activities. Using the capabilities of the Excel spreadsheet editor, we describe the dependence of the gross regional product on the size of capital investment in transport, warehousing, postal and courier activities (see Figure 1).

The regression equation is obtained in the form of a logarithmic curve that aligns the pattern of change with the coefficient of multiple determination equal to $\mathrm{R}^{2}=0,6573: y=334,04 \ln (x)-3279.8$

Therefore, it can be argued that under other equivalent conditions, the variation of the gross regional product by $65.73 \%$ depends on the variation of capital investment in transport, warehousing, postal and courier activities, and this dependence is a logarithmic regularity.

Table 4

Rank values of components and ranking of regions of Ukraine by the level of favourability for the development of the logistics-outsourcing system (compiled by the authors based on conducted calculations)

\begin{tabular}{|l|c|c|c|c|c|c|}
\hline Regions of Ukraine & $\mathrm{R}(l)$ & $\mathrm{R}(e)$ & $\mathrm{R}(t)$ & $\mathrm{R}(g)$ & $\mathrm{I}$ & Regions'ranking \\
\hline Vinnytsia & 108 & 64 & 21 & 19 & 212 & 9 \\
\hline Volyn & 30 & 56 & 33 & 19 & 138 & 20 \\
\hline Dnipropetrovsk & 157 & 85 & 39 & 35 & 316 & 1 \\
\hline Donetsk & 132 & 73 & 14 & 36 & 255 & 7 \\
\hline Zhytomyr & 84 & 76 & 7 & 23 & 190 & 12 \\
\hline Zakarpattia & 74 & 49 & 42 & 28 & 193 & 11 \\
\hline Zaporizhzhia & 108 & 82 & 26 & 34 & 250 & 8 \\
\hline Ivano-Frankivsk & 69 & 66 & 26 & 25 & 186 & 13 \\
\hline Kyiv & 128 & 72 & 46 & 19 & 265 & 5 \\
\hline Kirovohrad & 66 & 78 & 15 & 18 & 177 & 15 \\
\hline Luhansk & 85 & 33 & 3 & 40 & 161 & 17 \\
\hline Lviv & 127 & 90 & 44 & 28 & 289 & 3 \\
\hline Mykolaiv & 88 & 68 & 19 & 26 & 201 & 10 \\
\hline Odesa & 120 & 76 & 49 & 40 & 285 & 4 \\
\hline Poltava & 115 & 82 & 39 & 28 & 264 & 6 \\
\hline Rivne & 46 & 29 & 38 & 14 & 127 & 23 \\
\hline Sumy & 49 & 58 & 15 & 15 & 137 & 21 \\
\hline Ternopil & 53 & 36 & 32 & 13 & 134 & 22 \\
\hline Kharkiv & 140 & 87 & 34 & 37 & 298 & 2 \\
\hline Kherson & 62 & 48 & 36 & 39 & 185 & 14 \\
\hline Khmelnytskyi & 79 & 35 & 16 & 14 & 144 & 19 \\
\hline Cherkasy & 67 & 72 & 25 & 11 & 175 & 16 \\
\hline Chernivtsi & 55 & 35 & 7 & 47 & 145 & 24 \\
\hline Chernihiv & 34 & 37 & 27 & & & 18 \\
\hline
\end{tabular}




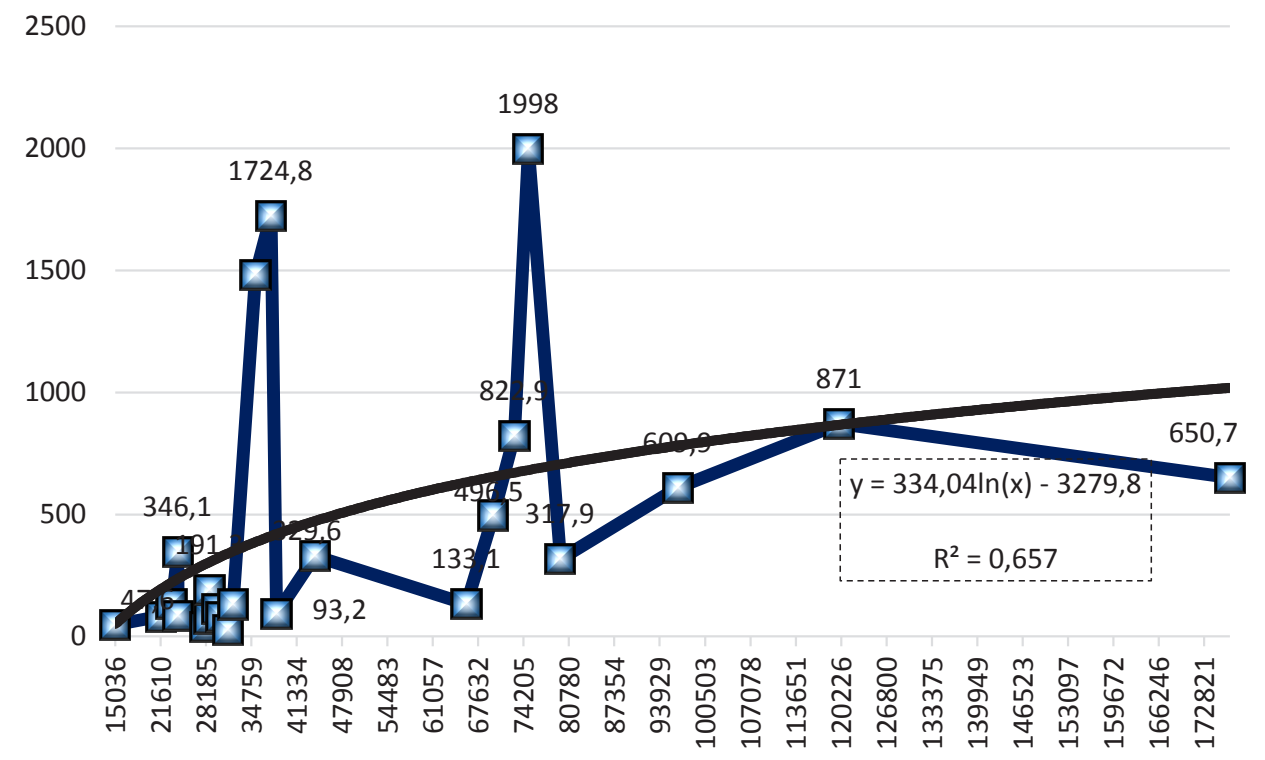

Figure 1. Dependence of the gross regional product on the size of capital investment in transport, warehousing, postal and courier activities (compiled by the authors according to data of the statistical collection "Regions of Ukraine, 2016" and the statistical collection "Transport and Communications of Ukraine - 2016")

\section{Conclusions and prospects for further research}

After analysing the current state of development of logistics services at the level of regions of Ukraine, it is possible to identify the key directions for further research in the areas of development of regional logistics infrastructure and outsourcing:

- ensuring availability and improving the quality of regional logistics-outsourcing services;

- integration of logistics of border regions and national transport system to European and international logistics systems;

- increasing the efficiency of public administration in the field of logistics;

- development of transport and logistics infrastructure;
- constant updating of fixed assets and information and technological systems of regional logistics;

- increase of investment attractiveness of regions;

- increasing the level of security of logistics processes;

- increasing environmental and energy efficiency of transportation.

The proposed methodology for assessing the favourability for the development of the logisticsoutsourcing system of regions is based on statistical indicators; however, it can be supplemented by other constituent indicators and expert assessments. If to consider and analyse in dynamics for a few years the results of such an assessment, this will allow improving the level of logistics services' development in Ukraine and increasing the competitiveness of the state in general and its regions.

\section{References:}

Illiashenko, S.M. (Eds.). (2009) Marketynh: bakalavrskyi kurs [Marketing: bachelor course]. Sumy: VTD «Universytetska knyha» [in Ukrainian].

Moroz, O.D. (2010) Metodyka ocinky peredumov formuvannja rehionalnykh lohistyčnykh system [Methodology for assessing the preconditions for the formation of regional logistics systems]. Dnipropetrovsk: $Z$ b. nauk. pr. "Ekonomičnyj prostir" - Collection of scientific works "Economic space", 36, 168-179 [in Ukrainian].

Syzdykbaieva, B., \& Raimbekov, Zh. (2013) Ocenka effektyvnosty razvytyja transportno-lohystyčeskoho potencyala rehyonov Kazakhstana [Estimation of efficiency of development of transport-logistical potential of regions of Kazakhstan]. Aktualni problemy ekonomiky - Actual problems of the economy, 5, 473-481 [in Ukrainian].

Freidman, O. A. (2013) Analyz lohystycheskoho potentsyala rehyona : monohrafyya [Analysis of the logistic potential of the region: monograph]. Yrkut.sk: YrHUPS [in Ukrainian.]

Rakhmanhulov, A.N., \& Kopylova, O.A. (2014) Otsenka sotsyalno-ekonomycheskoho potentsyala rehyona dlya razmeshchenyya obektov lohystycheskoy ynfrastruktury [Assessment of the socio-economic potential of the region for the accommodation of logistic infrastructure facilities]. Ekonomyka rehyona-Economy of the region, 2, $254-263$ [in Russian].

Oklander, M. A. (2008) Lohistyka: pidruchnyk [Logistics: textbook]. Kyiv: Tsentr uchbovoyi literatury [in Ukrainian]. 
Semenenko, \& A. Y. Serheev, V.Y. (2003) Lohystyka. Osnovy teoryy: uchebnyk dlya vuzov [Logistics Fundamentals of the theory: a textbook for high schools]. Yzdatelstvo «Soyuz» - Soyuz Publishing House [in Ukrainian]

Timonina, M. B. (Eds.). (2016) Statystychnyi zbirnyk «Rehiony Ukrayiny, 2016 (Chastyna II)» [Statistical collection «Regions of Ukraine, 2016 (Part II)»]. Kyiv: Derzhstat Ukrayiny [in Ukrainian].

Karmazina, O. O. (Eds.). (2016) Statystychnyi zbirnyk «Transport i zvyazok Ukrayiny - 2016» [Statistical Collection "Transport and Communications of Ukraine - 2016"]. Kyiv: Derzhstat Ukrayiny [in Ukrainian].

Stratehiya rozvytku Dnipropetrovskoyi oblasti na period do 2020 roku. [Strategy of the development of Dnipropetrovsk region up to 2020]. Retrieved from: http://www.minregion.gov.ua/napryamki-diyalnosti/ regional-dev/derzhavna-rehional-na-polityka/strategichne-planuvannya-regionalnogo-rozvitku [in Ukrainian]. 